\title{
Glycogen production for biofuels by the euryhaline cyanobacteria Synechococcus sp. strain PCC 7002 from an oceanic environment
}

Shimpei Aikawa ${ }^{1,2 \dagger}$, Atsumi Nishida ${ }^{1 \dagger}$, Shih-Hsin $\mathrm{Ho}^{3}$, Jo-Shu Chang ${ }^{4,5,6}$, Tomohisa Hasunuma ${ }^{3,7}$ and Akihiko Kondo ${ }^{1,2,8,9^{*}}$

\begin{abstract}
Background: Oxygenic photosynthetic microorganisms such as cyanobacteria and microalgae have attracted attention as an alternative carbon source for the next generation of biofuels. Glycogen abundantly accumulated in cyanobacteria is a promising feedstock which can be converted to ethanol through saccharification and fermentation processes. In addition, the utilization of marine cyanobacteria as a glycogen producer can eliminate the need for a freshwater supply. Synechococcus sp. strain PCC 7002 is a fast-growing marine coastal euryhaline cyanobacteria, however, the glycogen yield has not yet been determined. In the present study, the effects of light intensity, $\mathrm{CO}_{2}$ concentration, and salinity on the cell growth and glycogen content were investigated in order to maximize glycogen production in Synechococcus sp. strain PCC 7002.

Results: The optimal culture conditions for glycogen production in Synechococcus sp. strain PCC 7002 were investigated. The maximum glycogen production of $3.5 \mathrm{~g} \mathrm{~L}^{-1}$ for 7 days (a glycogen productivity of $0.5 \mathrm{~g} \mathrm{~L}^{-1}$ $\mathrm{d}^{-1}$ ) was obtained under a high light intensity, a high $\mathrm{CO}_{2}$ level, and a nitrogen-depleted condition in brackish water. The glycogen production performance in Synechococcus sp. strain PCC 7002 was the best ever reported in the a-polyglucan (glycogen or starch) production of cyanobacteria and microalgae. In addition, the robustness of glycogen production in Synechococcus sp. strain PCC 7002 to salinity was evaluated in seawater and freshwater. The peak of glycogen production of Synechococcus sp. strain PCC 7002 in seawater and freshwater were 3.0 and $1.8 \mathrm{~g} \mathrm{~L}^{-1}$ in 7 days, respectively. Glycogen production in Synechococcus sp. strain PCC 7002 maintained the same level in seawater and half of the level in freshwater compared with the optimal result obtained in brackish water.
\end{abstract}

Conclusions: We conclude that Synechococcus sp. strain PCC 7002 has high glycogen production activity and glycogen can be provided from coastal water accompanied by a fluctuation of salinity. This work supports Synechococcus sp. strain PCC 7002 as a promising carbohydrate source for biofuel production.

Keywords: Carbon source, Cyanobacteria, Glycogen, Salinity, Synechococcus sp. strain PCC 7002

\footnotetext{
* Correspondence: akondo@kobe-u.ac.jp

${ }^{\dagger}$ Equal contributors

'Department of Chemical Science and Engineering, Graduate School of

Engineering, Kobe University, 1-1 Rokkodai, Nada, Kobe 657-8501, Japan

${ }^{2}$ Core Research for Evolutional Science and Technology, Japan Science and

Technology Agency, 3-5 Sanban, Chiyoda, Tokyo 102-0075, Japan

Full list of author information is available at the end of the article
} 


\section{Background}

Currently, biorefinery, including production of biofuels and bio-based chemicals, has received considerable attention. Additionally, environmental concerns and the depletion of oil reserves have resulted in promoting research on more environmentally benign and sustainable biofuels such as bioethanol.

Oxygenic photosynthetic microorganisms, including cyanobacteria and microalgae, have attracted attention as an alternative carbon source for biorefineries [1-3]. Cyanobacteria and microalgae convert solar energy to biomass more efficiently ( 0.5 to $2.0 \%$ efficiency) than energy crops such as switchgrass (0.2\% efficiency) [4], and their $\alpha$ polyglucans such as glycogen from cyanobacteria or starch from microalgae, can be converted to bioethanol by yeast fermentation [5-9]. In addition, they are capable of growing in aquatic environments, providing the additional benefit of whole-year cultivation using non-arable land. In particular, the cultivation of cyanobacteria and microalgae using seawater or brackish water eliminates the impact on freshwater resources [10]. These carbohydrate-producing species need to tolerate a wide salinity range because the salinity of coastal water fluctuates with changes in freshwater inflow by climate, weather, and diurnal tidal current. Therefore, in the current study, the euryhaline cyanobacteria Synechococcus sp. strain PCC 7002, which is wellsuited for growing in a coastal region, was selected as a carbohydrate producer. Synechococcus sp. strain PCC 7002 is naturally transformable and its genome has been fully sequenced [11]. Based on these superior characteristics, Synechococcus sp. strain PCC 7002 is a model organism for research on cyanobacterial metabolites and is expected to be a platform for biotechnological applications by metabolic engineering [12-17].

According to definition, glycogen productivity is estimated from glycogen content and biomass productivity. To improve glycogen productivity in cyanobacteria, both the glycogen content and biomass productivity need to be enhanced. In general, glycogen is accumulated via nitrogen depletion in many cyanobacteria species, such as Synechococcus sp. strain PCC 7002, Synechocystis sp. strain PCC 6803, Arthrospira platensis, Arthrospira maxima, Anabaena variabilis, and Anacystis nidulans [16-23]. Unfortunately, high glycogen content is generated under nitrogen depletion which is associated with low biomass productivity $[19,23]$. Hence, it is important to obtain a high biomass productivity with a satisfactory glycogen content. However, the integral effect of growth conditions on glycogen production in Synechococcus sp. strain PCC 7002 has not been fully investigated.

In the present study, the glycogen production activity of euryhaline cyanobacteria Synechococcus sp. strain PCC 7002 was examined under several combined growth conditions, including $\mathrm{CO}_{2}$ concentration, light intensity, salinity, and nitrate supply.

\section{Results}

Effect of light intensity and $\mathrm{CO}_{2}$ concentration on cell growth

Light intensity and $\mathrm{CO}_{2}$ concentration are the key environmental factors for cyanobacterial cell growth [1]. In this study, Synechococcus sp. strain PCC 7002 was cultivated on medium A for 7 days under a light intensity of 50 to $600 \mu \mathrm{mol}$ photons $\mathrm{m}^{-2} \mathrm{~s}^{-1}$ with various $\mathrm{CO}_{2}$ concentrations as depicted in Figure 1 (for example, 0.04 to $4 \% \mathrm{CO}_{2}$ in air). As shown in Figure 1a, cell growth in $0.04 \% \mathrm{CO}_{2}$ in air (the atmospheric $\mathrm{CO}_{2}$ level) was not altered by an increase in light intensity. On the other hand, the cell density of Synechococcus sp. strain PCC 7002 tended to increase when increasing $\mathrm{CO}_{2}$ concentration from 0.04 to $2 \%$ and increasing light intensity from 50 to $600 \mu \mathrm{mol}$ photons $\mathrm{m}^{-2} \mathrm{~s}^{-1}$. However, further increases in $\mathrm{CO}_{2}$ concentration to $4 \%$ resulted in no significant difference in cell growth under low and high light intensity, suggesting that excess $\mathrm{CO}_{2}$ supply (4\%) would not provide a positive effect on cell growth. According to Figure 1, Synechococcus sp. strain PCC 7002 cultivated under conditions of high $\mathrm{CO}_{2}$ concentration (2 and 4\% $\mathrm{CO}_{2}$ ) with high illumination $\left(600 \mu \mathrm{mol}\right.$ photons $\left.\mathrm{m}^{-2} \mathrm{~s}^{-1}\right)$ reached the highest cell density of around $9 \mathrm{~g} \mathrm{~L}^{-1}$ after 7 days of cultivation. Thus, both enriched $\mathrm{CO}_{2}$ supply and high light intensity enhanced the cell growth of Synechococcus sp. strain PCC 7002.

\section{Effect of light intensity and $\mathrm{CO}_{2}$ concentration on glycogen content and glycogen production}

Light intensity and $\mathrm{CO}_{2}$ supply do not only influence the growth of photosynthetic organism but also alter their carbohydrate content [24-26]. Therefore, in this study, the effect of light intensity (50 to $600 \mu \mathrm{mol}$ photons $\mathrm{m}^{-2} \mathrm{~s}^{-1}$ ) and $\mathrm{CO}_{2}$ concentration (such as 0.04 to $4 \% \mathrm{CO}_{2}$ ) on glycogen content were explored, as shown in Figure 2a. Glycogen content increased with an increase in light intensity from 50 to $600 \mu \mathrm{mol}$ photons $\mathrm{m}^{-2} \mathrm{~s}^{-1}$.

As shown in Figure 2a, the glycogen content under $300 \mu \mathrm{mol}$ photons $\mathrm{m}^{-2} \mathrm{~s}^{-1}$ increased from 0.8 to $19 \%$ as the $\mathrm{CO}_{2}$ concentration increased from 0.04 to $1 \%$, and under the same range of $\mathrm{CO}_{2}$ concentrations at $600 \mu \mathrm{mol}$ photons $\mathrm{m}^{-2} \mathrm{~s}^{-1}$, it increased from 9.4 to $31 \%$. However, further increase in $\mathrm{CO}_{2}$ concentration to $2 \%$ under 300 or $600 \mu \mathrm{mol}$ photons $\mathrm{m}^{-2} \mathrm{~s}^{-1}$ did not enhance glycogen content.

Glycogen production under 50 to $600 \mu \mathrm{mol}$ photons $\mathrm{m}^{-2} \mathrm{~s}^{-1}$ in 0.04 to $4 \% \mathrm{CO}_{2}$ after 7 days was calculated from biomass production and glycogen content, as shown in Figure $2 \mathrm{~b}$. The maximum glycogen production of $2.5 \mathrm{~g} \mathrm{~L}^{-1}$ was obtained under $600 \mu$ mol photons $\mathrm{m}^{-2} \mathrm{~s}^{-1}$ in $2 \% \mathrm{CO}_{2}$. Hence, glycogen production in Synechococcus sp. strain PCC 7002 was significantly improved by the combined optimization of $\mathrm{CO}_{2}$ concentration and light intensity. 

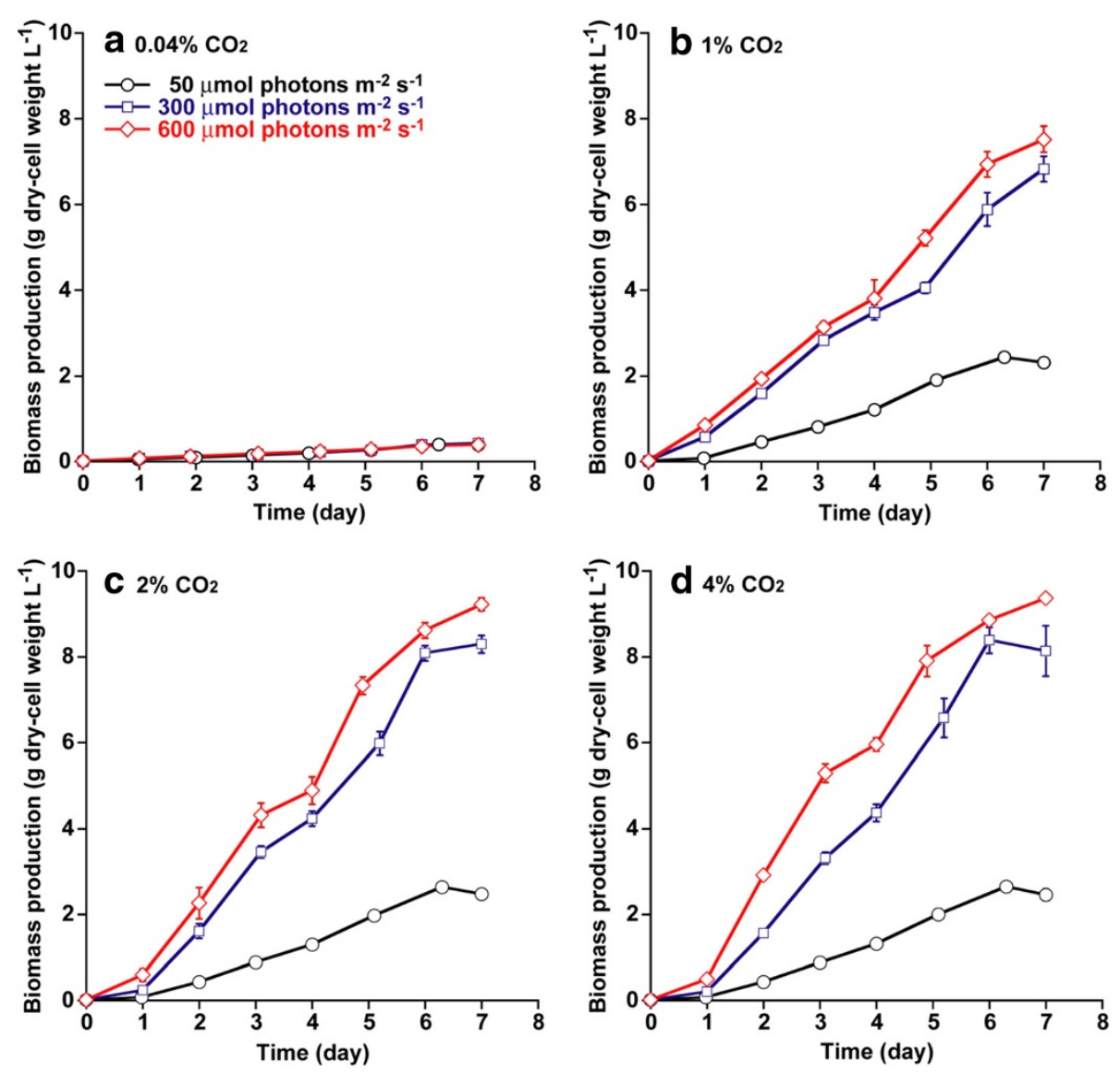

Figure 1 Growth curve under different light intensities and $\mathrm{CO}_{2}$ concentrations. (a) Growth curve under $0.04 \% \mathrm{CO}_{2} ;$ (b), $1 \% \mathrm{CO}_{2} ;$ (c), $2 \%$ $\mathrm{CO}_{2}$; and (d), 4\% $\mathrm{CO}_{2}$. Light intensities are 50 (circles), 300 (squares), and $600 \mu \mathrm{mol}$ photons $\mathrm{m}^{-2} \mathrm{~s}^{-1}$ (diamonds). Error bars indicate standard deviations (SD) of three replicated experiments. In some data points, error bars obtained by three replications are smaller than symbols.

Effect of nitrate supply in different salinity media on glycogen production under high light and high $\mathrm{CO}_{2}$ conditions

The accumulation of glycogen occurs in many cyanobacteria, such as Synechococcus sp. strain PCC 7002, Synechocystis sp. strain PCC 6803, A. platensis, A. maxima, A. variabilis, and $A$. nidulans, under nitrogen-depleted conditions [16-23]. However, high levels of glycogen are generated under nitrogen depletion, which is associated with low biomass productivity $[19,23]$. Therefore, in this study, the effect of nitrate
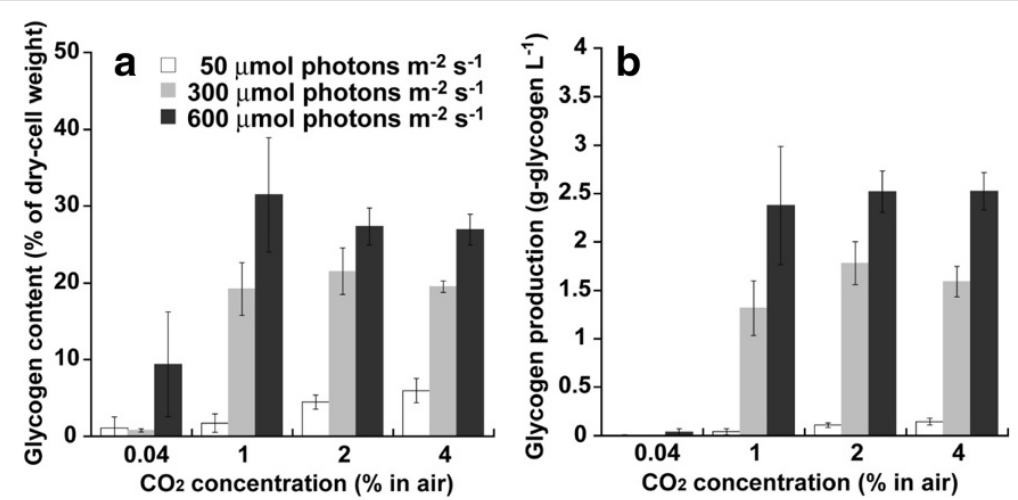

Figure 2 Glycogen content and glycogen production after 1 week under different light intensities and $\mathrm{CO}_{2}$ concentrations.

(a) Glycogen content; (b) glycogen production. Light intensities are 50 (white bars), 300 (gray bars), and 600 mmol photons $\mathrm{m}^{-2} \mathrm{~s}^{-1}$ (Black bars). Data points are mean values from three separate cultures with SD of triplicates. 
supply on both glycogen content and biomass production in Synechococcus sp. strain PCC 7002 under $600 \mu \mathrm{mol}$ photons $\mathrm{m}^{-2} \mathrm{~s}^{-1}$ and $2 \% \mathrm{CO}_{2}$ was investigated. Additionally, in case of cultivation in brackish water or seawater at a coastal region, the salinity of medium was fluctuated according to climate, weather, and diurnal tidal current. Therefore, to estimate the glycogen productivity of Synechococcus sp. strain PCC 7002 under different salinity conditions, the glycogen content and biomass production in brackish water (Figure 3a), seawater (Figure 3b), and freshwater (Figure 3c) media were examined. The glycogen content of Synechococcus sp. strain PCC 7002 in all media increased with a drop of nitrate concentration from 27 to $9 \mathrm{mM}$, reaching 52, 50, or $62 \%$ of dry-cell weight in brackish water, seawater, or freshwater medium, respectively. Unfortunately, the biomass productions were suppressed below $21 \mathrm{mM}$ in brackish water and below $15 \mathrm{mM}$ in seawater (Figure 3a,b). Thus, in this study, the glycogen production of Synechococcus sp. strain PCC 7002 in each medium was calculated in order to optimize the nitrate concentration to obtain a suitable combination of biomass production and glycogen content, as shown in Figure 3d. The peak of glycogen production was $3.5 \mathrm{~g} \mathrm{~L}^{-1}$ in brackish water with 13 and $15 \mathrm{mM}$ nitrate, $3.0 \mathrm{~g} \mathrm{~L}^{-1}$ in seawater with $15 \mathrm{mM}$ nitrate, or $1.8 \mathrm{~g} \mathrm{~L}^{-1}$ in freshwater with $9 \mathrm{mM}$ nitrate (Figure 3d). Glycogen production in Synechococcus sp. strain PCC 7002 maintained the same level in seawater and half of the level in freshwater compared with the level achieved in brackish water.

\section{Discussion}

Cyanobacterial glycogen is remarkable carbon source for bioethanol production by yeast fermentation [5]. As shown in Figure 2a, glycogen accumulated under high light intensity and high $\mathrm{CO}_{2}$ concentration. In vitro and in situ kinetic experiments have revealed that cyanobacterial glycogen synthesis is regulated by adenosine diphosphate (ADP)-glucose pyrophosphorylase (AGPase) activity, which is enhanced by 3 -phosphoglycerate (3-PG) accumulation and inhibited by inorganic phosphorus accumulation [27]. Therefore, 3-PG might be accumulated by the increase in light intensity and $\mathrm{CO}_{2}$ concentration, which would lead to glycogen accumulation in Synechococcus sp. strain PCC 7002 .

The glycogen production of Synechococcus sp. strain PCC 7002 was examined under different nitrate additions in a brackish water medium (Figure 3a). As shown in Additional file 1: Figure S1, cell growth in brackish water media under
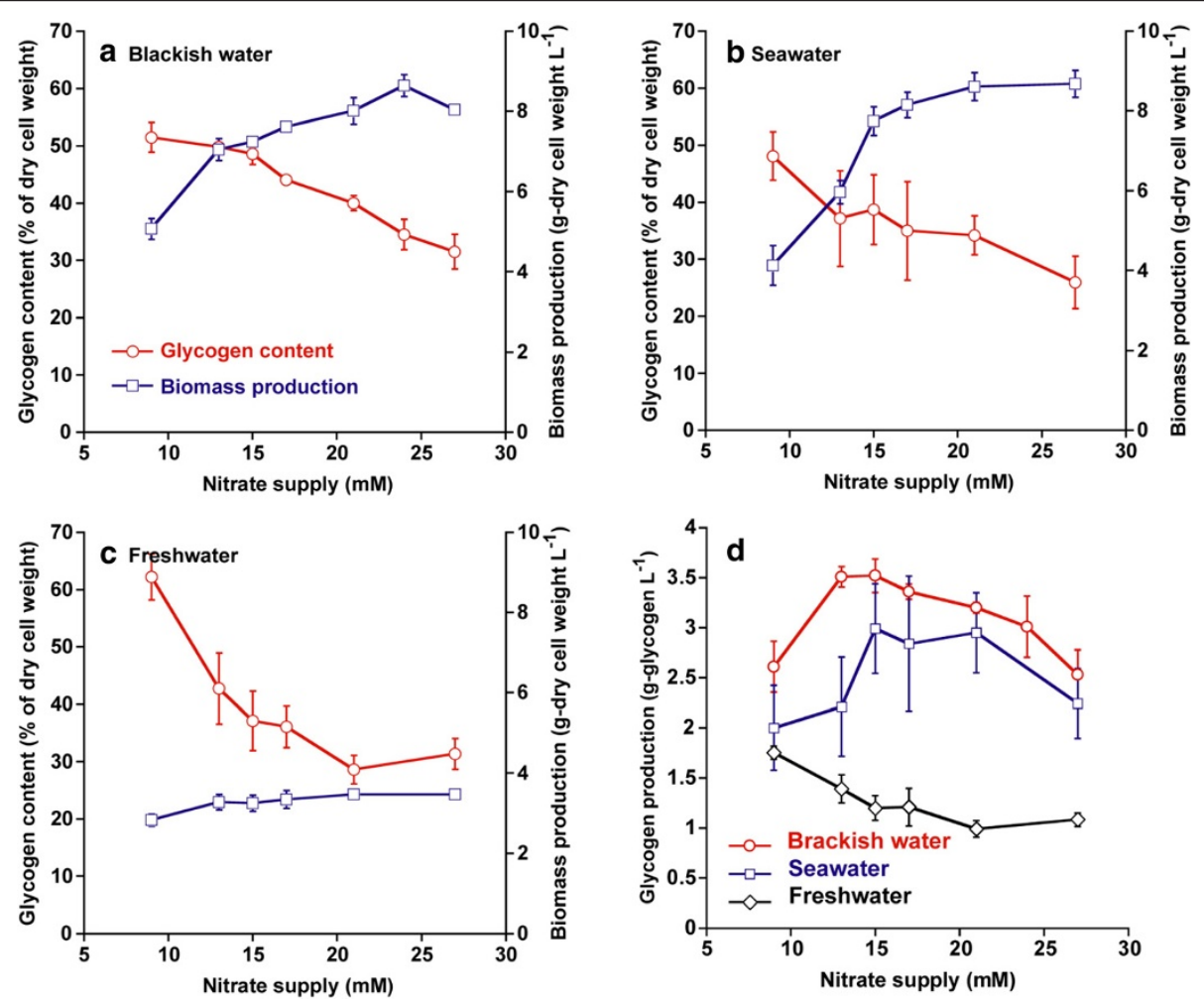

Figure 3 Biomass production, glycogen content, and glycogen production after 1 week under different salinity conditions. (a) Biomass production (circles) and glycogen content (squares) in brackish water; (b) in seawater; and (c) in freshwater; (d) glycogen production under different nitrate supplies in brackish water (circles), seawater (squares), and freshwater (diamonds). Cells were cultivated under $600 \mu \mathrm{mol}$ photons $\mathrm{m}^{-2} \mathrm{~s}^{-1}$ and $2 \% \mathrm{CO}_{2}$. Data points are mean values from three separate cultures with SD of triplicates. 
9 and $15 \mathrm{mM}$ nitrate supplies were inhibited by nitrogen limitation. Under nitrogen-limiting conditions, biomass production would be strongly inhibited due to the relatively low photosynthesis efficiency, expecting that lightharvesting proteins (such as phycobiliproteins) would be degraded to compensate for the insufficient nitrogen availability [28]. On the other hand, the glycogen content in cyanobacteria is accumulated by nitrogen depletion [16-20]. Since lower initial nitrate supplies caused faster nitrate depletion (as shown in Additional file 2: Figure S2), glycogen content increased gradually with a decrease in initial supplied nitrate as shown in Figure 3a.

In addition, glycogen production was influenced by salinity in medium as shown in Figure 3a-d. Glycogen production in seawater was a little lower than brackish water, which was caused by the lower glycogen content (Figure 3a,b,d). Glycogen content in seawater would be reduced by the accumulation of osmolytes, such as glucosylglycerol, glucosylglycerate, and sucrose in Synechococcus sp. strain PCC 7002, with an increase in sodium chloride concentration $[16,17,30]$. Also, the decline of glycogen production in freshwater was due to lower biomass production (Figure 3a,c,d). High cell density in Synechococcus sp. strain PCC 7002 could not be obtained in the freshwater medium.

The biomass production and $\alpha$-polyglucan production in various cyanobacteria and microalgae are summarized in Table 1. The highest biomass production $\left(7.2 \mathrm{~g} \mathrm{~L}^{-1}\right)$ and $\alpha$-polyglucan production $\left(3.5 \mathrm{~g} \mathrm{~L}^{-1}\right)$ from Synechococcus sp. strain PCC 7002 under the optimal conditions with the brackish water medium are higher than that reported by other studies [19,21,22,25,30-36]. In addition, glycogen production of Synechococcus sp. strain PCC 7002 in a seawater and freshwater environment is greater than or similar with other cyanobacteria and microalgae as shown in Table 1. Therefore, Synechococcus sp. strain PCC 7002 would not only provide glycogen from coastal seawaters without the need for freshwater resources, but also can produce the highest level of $\alpha$ polyglucan among microalgae and cyanobacteria in wide salinity conditions.

To further improve glycogen productivity in Synechococcus sp. strain PCC 7002, the glycogen accumulation rate should be accelerated through metabolic engineering. According to Kumaraswamy et al., the intracellular glycogen content in Synechococcus sp. strain PCC 7002 is positively correlated with the expression level of the $\mathrm{NAD}^{+}$-dependent glyceraldehyde 3-phosphate dehydrogenase (GAPDH-1) gene under photoautotrophic conditions [15]. Accordingly, glycogen productivity in Synechococcus sp. strain PCC 7002 may be further improved by a combination of the optimization of growth conditions and the overexpression of GAPDH-1. Glycogen produced by Synechococcus sp. strain PCC 7002 in this study was converted to ethanol by yeast fermentation (Additional file 3: Figure S3). The enhancement of glycogen production by Synechococcus sp. strain PCC 7002 would contribute to biofuel production.

\section{Conclusions}

Synechococcus sp. strain PCC 7002 which combines a wide salinity tolerance and high glycogen production capacity could become an important carbon source for the development of biofuels and bio-based chemicals production. The glycogen productivity of Synechococcus sp. strain PCC 7002 would be further enhanced through genetic engineering or metabolic engineering in the next step, which could accelerate the glycogen accumulation rate under nitrogen depletion.

\section{Methods}

\section{Microorganism and growth conditions}

The cyanobacteria Synechococcus sp. strain PCC 7002 was obtained from the Pasteur Culture Collection (Paris, France). Cells were pre-cultured in $500 \mathrm{~mL}$ Erlenmeyer flasks containing $250 \mathrm{~mL}$ of modified medium A $\left(3.0 \mathrm{~g} \mathrm{~L}^{-1}\right.$ $\mathrm{NaNO}_{3}, 50 \mathrm{mg} \mathrm{L}^{-1} \mathrm{KH}_{2} \mathrm{PO}_{4}, 18 \mathrm{~g} \mathrm{~L}^{-1} \mathrm{NaCl}, 5.0 \mathrm{~g} \mathrm{~L}^{-1}$ $\mathrm{MgSO}_{4} \cdot 7 \mathrm{H}_{2} \mathrm{O}, 0.37 \mathrm{~g} \mathrm{~L}^{-1} \mathrm{CaCl}_{2} \cdot 2 \mathrm{H}_{2} \mathrm{O}, 0.60 \mathrm{~g} \mathrm{~L}^{-1} \mathrm{KCl}$, $32 \mathrm{mg} \mathrm{L} \mathrm{L}^{-1} \mathrm{Na}_{2} \mathrm{EDTA} \cdot 2 \mathrm{H}_{2} \mathrm{O}, 8.0 \mathrm{mg} \mathrm{L}{ }^{-1} \mathrm{FeCl}_{3} \cdot 6 \mathrm{H}_{2} \mathrm{O}$, $34 \mathrm{mg} \mathrm{L}^{-1} \mathrm{H}_{3} \mathrm{BO}_{3}, 4.3 \mathrm{mg} \mathrm{L}^{-1} \mathrm{MnCl}_{2} \bullet 4 \mathrm{H}_{2} \mathrm{O}, 0.32 \mathrm{mg} \mathrm{L}^{-1}$ $\mathrm{ZnCl}_{2}, 30 \mu \mathrm{g} \mathrm{L}^{-1} \mathrm{MoO}_{3}, 3.0 \mu \mathrm{g} \mathrm{L}^{-1} \mathrm{CuSO}_{4} \cdot 5 \mathrm{H}_{2} \mathrm{O}, 12 \mu \mathrm{g} \mathrm{L}^{-1}$ $\mathrm{CoCl}_{2} \cdot 6 \mathrm{H}_{2} \mathrm{O}, 4.0 \mu \mathrm{g} \mathrm{L}^{-1}$ cobalamin, and $8.3 \mathrm{mM}$ Tris aminomethane, all of which were purchased from Nacalai Teque, Inc., (Kyoto, Japan)) [37] with $100 \mathrm{rpm}$ agitation under continuous illumination at $50 \mu \mathrm{mol}$ photons $\mathrm{m}^{-2} \mathrm{~s}^{-1}$ for 7 days in air at $30 \pm 2{ }^{\circ} \mathrm{C}$ in an NC350-HC plant chamber (Nippon Medical and Chemical Instruments, Osaka, Japan). Experiments were carried out in a closed double-deck flask, containing in the first stage $50 \mathrm{~mL}$ of $2 \mathrm{M} \mathrm{NaHCO} / \mathrm{Na}_{2} \mathrm{CO}_{3}$ buffer with the appropriate $\mathrm{pH}$ to obtain the desired $\mathrm{CO}_{2}$ concentration [38,39], and containing in the second stage $70 \mathrm{~mL}$ of culture medium. $\mathrm{NaHCO}_{3} / \mathrm{Na}_{2} \mathrm{CO}_{3}$ buffer was exchanged after 4 days to maintain the desired $\mathrm{CO}_{2}$ concentration. Pre-cultured cells were inoculated into fresh medium at a dry-based biomass concentration of $0.01 \mathrm{~g}$ dry-cell weight $\mathrm{L}^{-1}$ (the optical density at $750 \mathrm{~nm}$ (OD750) value was 0.04 ) and cultivated for 7 days at $33 \pm 3{ }^{\circ} \mathrm{C}$ with $80 \mathrm{rpm}$ agitation. The effects of light intensity and $\mathrm{CO}_{2}$ concentration on glycogen production were examined under 50,300, or $600 \mu \mathrm{mol}$ photons $\mathrm{m}^{-2} \mathrm{~s}^{-1}$ at 0.04 (atmospheric level), 1, 2, or $4 \%(\mathrm{v} / \mathrm{v}) \mathrm{CO}_{2}$ in air. Light intensity was measured in the middle of the medium using an LI-250A light meter (LICOR, Lincoln, Nebraska, USA) equipped with an LI-190SA quantum sensor (LI-COR). To study the effect of nitrate supply in different salinity media under $600 \mu \mathrm{mol}$ photons $\mathrm{m}^{-2} \mathrm{~s}^{-1}$ in $2 \% \mathrm{CO}_{2}$ in air, pre-cultured cells were transferred into 3-types of media with 9 to $35 \mathrm{mM}$ nitrate. : 1) medium A (brackish water medium; salinity at $2.7 \%$ ), 2) medium A containing $0.075 \mathrm{~g} \mathrm{~L} \mathrm{~L}^{-1} \mathrm{MgSO}_{4} \cdot 7 \mathrm{H}_{2} \mathrm{O}, 0.036 \mathrm{~g} \mathrm{~L} \mathrm{~L}^{-1}$ 
Table 1 Production of biomass and a-polyglucan by microalgae and cyanobacteria under phototrophic condition

\begin{tabular}{|c|c|c|c|c|c|c|c|c|}
\hline Species & $\begin{array}{l}\text { Biomass production } \\
\left.\text { (g-dry biomass } \mathrm{L}^{-1}\right)\end{array}$ & $\begin{array}{c}\text { a-polyglucan } \\
\text { production }\left(\mathrm{g} \mathrm{L}^{-1}\right)\end{array}$ & $\begin{array}{l}\text { a-polyglucan content } \\
\text { (\% of dry biomass) }\end{array}$ & $\begin{array}{c}\text { Light intensity } \\
\left(\mu \mathrm{mol} \text { photons } \mathrm{m}^{-2} \mathrm{~s}^{-1}\right)\end{array}$ & $\begin{array}{c}\text { Nitrogen } \\
\text { source }\end{array}$ & Carbon source & Medium & Reference \\
\hline Porphyridium sp. UTEX 637 & 5.6 & 0.36 & 6.7 & 300 & $10 \mathrm{mM} \mathrm{KNO}_{3}$ & $1.5-2 \% \mathrm{CO}_{2}$ aeration & Seawater & {$[30]$} \\
\hline Porphyridium aerugineum & 5.0 & 0.63 & 12.7 & 300 & $5.2 \mathrm{mM} \mathrm{NaNO}_{3}$ & $1.5-2 \% \mathrm{CO}_{2}$ aeration & Freshwater & \\
\hline Tetraselmis subcordiformis & 5.7 & 2.7 & 47.8 & 200 & $11 \mathrm{mM} \mathrm{KNO}_{3}$ & $3 \% \mathrm{CO}_{2}$ aeration & Seawater & [31] \\
\hline $\begin{array}{l}\text { Chlorella vulgaris CCAP } \\
211 / 11 \mathrm{~B}\end{array}$ & 2.4 & 1.3 & 55.0 & 300 & $6 \mathrm{mM} \mathrm{KNO}_{3}$ & $2 \% \mathrm{CO}_{2}$ aeration & Freshwater & [32] \\
\hline Arthrospira maxima SOSA 18 & 0.95 & 0.91 & 70.0 & 50 & No addition & $200 \mathrm{mM} \mathrm{HCO}_{3}^{-}$ & High sodium water ${ }^{a}$ & [21] \\
\hline Arthrospira platensis NIES-39 & 1.6 & 1.0 & 63.0 & 700 & $3 \mathrm{mM} \mathrm{NaNO}_{3}$ & $200 \mathrm{mM} \mathrm{HCO}_{3}^{-}$ & High sodium water ${ }^{a}$ & [19] \\
\hline Arthrospira platensis NIES-46 & 1.1 & 0.58 & 53.0 & 50 & No addition & $200 \mathrm{mM} \mathrm{HCO}_{3}^{-}$ & High sodium water ${ }^{a}$ & [33] \\
\hline $\begin{array}{l}\text { Anabaena variabilis } \\
\text { ATCC } 29413\end{array}$ & 0.3 & 0.08 & 26.7 & 50 & No addition & $1.5 \% \mathrm{CO}_{2}$ aeration & Freshwater & [22] \\
\hline Gloeocapsa alpicola CALU 743 & N.D. & 0.60 & N.D. & 220 & $4 \mathrm{mM} \mathrm{KNO}_{3}$ & $2 \% \mathrm{CO}_{2}$ aeration & Freshwater & [34] \\
\hline $\begin{array}{l}\text { Plectonema boryanum } \\
\text { ATCC } 18200\end{array}$ & 0.34 & 0.08 & 22.0 & 100 & $\begin{array}{c}0.5 \mathrm{mM} \\
\mathrm{Ca}\left(\mathrm{NO}_{3}\right)_{2} \cdot 4 \mathrm{H}_{2} \mathrm{O}\end{array}$ & Air & Freshwater & [35] \\
\hline Synechocystis sp. PCC 6701 & N.D. & 0.46 & N.D. & 40 & No addition & $1 \% \mathrm{CO}_{2}$ aeration & Freshwater & [36] \\
\hline \multirow[t]{4}{*}{ Synechococcus sp. PCC 7002} & N.D. & 0.33 & N.D. & 2500 & $11 \mathrm{mM} \mathrm{NaNO}_{3}$ & $1 \% \mathrm{CO}_{2}$ & Brackish water & [25] \\
\hline & 7.2 & 3.5 & 49.8 & 600 & $15 \mathrm{mM} \mathrm{NaNO}_{3}$ & $2 \% \mathrm{CO}_{2}$ & Brackish water & This work \\
\hline & 7.7 & 3.0 & 38.7 & 600 & $15 \mathrm{mM} \mathrm{NaNO}_{3}$ & $2 \% \mathrm{CO}_{2}$ & Seawater & \\
\hline & 2.8 & 1.8 & 62.2 & 600 & $9 \mathrm{mM} \mathrm{NaNO}_{3}$ & $2 \% \mathrm{CO}_{2}$ & Freshwater & \\
\hline
\end{tabular}


$\mathrm{CaCl}_{2} \cdot 2 \mathrm{H}_{2} \mathrm{O}, 0.04 \mathrm{~g} \mathrm{~L}^{-1} \mathrm{~K}_{2} \mathrm{HPO}_{4}$ without $\mathrm{NaCl}$ (freshwater medium; salinity at $0.3 \%$ ), 3) medium A containing $29.2 \mathrm{~g} \mathrm{~L}^{-1} \mathrm{NaCl}, 7 \mathrm{~g} \mathrm{~L}^{-1} \quad \mathrm{MgSO}_{4} \cdot 7 \mathrm{H}_{2} \mathrm{O}, 4 \mathrm{~g} \mathrm{~L} \mathrm{~L}^{-1}$ $\mathrm{MgCl}_{2} \cdot 6 \mathrm{H}_{2} \mathrm{O}, 1.47 \mathrm{~g} \mathrm{~L}^{-1} \mathrm{CaCl}_{2} \cdot 2 \mathrm{H}_{2} \mathrm{O}, 0.6 \mathrm{~g} \mathrm{~L}^{-1} \mathrm{KCl}$, $0.05 \mathrm{~g} \mathrm{~L}^{-1} \mathrm{KH}_{2} \mathrm{PO}_{4}$ (seawater medium; salinity at $4.0 \%$ ). Medium salinity were measured with a refractometer ( $\mathrm{S} /$ Mill-E; Atago Co. Ltd, Tokyo, Japan).

\section{Analytical methods}

Cell growth was monitored by measuring OD750 in a spectrophotometer (UVmini-1240, Shimadzu, Kyoto, Japan) [29]. Cell concentration was shown as dry-cell weight during cultivation and was converted using a pre-established calibration between dry-cell weight and optical density of cell suspension (1.0 OD750 equals approximately $0.32 \mathrm{~g}$ dry-cell weight $\left.\mathrm{L}^{-1}\right)$. Dry-cell weight was determined by centrifugation of serial diluted cell-suspension $(6,300 \times \mathrm{g}$ for 2 minutes at $25^{\circ} \mathrm{C}$ ), washing the pellet once with $0.3 \mathrm{M}$ ammonium carbonate and lyophilization.

Glycogen content and concentration were determined by high performance liquid chromatography (HPLC) (Shimadzu, Kyoto, Japan) using a size exclusion HPLC column (OHpak SB-806 M HQ; Shodex, Tokyo, Japan) and a reflective index detector (RID-10A; Shimadzu, Kyoto, Japan) [40]. Glycogen was extracted from the dried cells by the modified method of Ernst and Böger [22]. Glycogen productivity $\left(\mathrm{g} \mathrm{L}^{-1} \mathrm{~d}^{-1}\right)$ was estimated by dividing glycogen production by cultivation time. Experimental data were means of triplicate samples and error bars in the figures indicate the standard deviation.

\section{Additional files}

Additional file 1: Figure S1. Growth curve under different nitrate supplies in brackish water medium. Cells were cultivated under $600 \mu \mathrm{mol}$ photons $\mathrm{m}^{-2} \mathrm{~s}^{-1}$ and $2 \% \mathrm{CO}_{2}$ condition with 9 to $27 \mathrm{mM}$ nitrate supplies. Error bars indicate standard deviations (SD) of three replicated experiments. In some data points, error bars obtained by three replications are smaller than symbols.

Additional file 2: Figure S2. Nitrate consumption under different nitrate supplies in brackish water medium. Nitrate concentrations were determine according to method proposed by American Public Health Association [41]. Cells were cultivated under $600 \mu \mathrm{mol}$ photons $\mathrm{m}^{-2} \mathrm{~s}^{-1}$ and $2 \% \mathrm{CO}_{2}$ from 35 to $9 \mathrm{mM}$ nitrate supplies. Error bars indicate standard deviations (SD) of three replicated experiments. In some data points, error bars obtained by three replications are smaller than symbols.

Additional file 3: Figure S3. Ethanol production from glycogen extracts of Synechococcus sp. strain PCC 7002 following yeast fermentation. Ethanol was produced from glycogen extracts of Synechococcus sp. strain PCC 7002 by Saccharomyces cerevisiae MT8-1 in the presence of $0.3 \cup \mathrm{L}^{-1}$ a-amylase and $0.1 \mathrm{U} \mathrm{L}^{-1}$ glucoamylase. Glycogen extracts of Synechococcus sp. strain PCC 7002 were prepared as described in Methods and then adjusted to $\mathrm{pH} 7.0$ using $98 \% \mathrm{H}_{2} \mathrm{SO}_{4}$ (w/w). S. cerevisiae MT8-1 cells were grown aerobically in 1-L Erlenmeyer flasks containing $500 \mathrm{~mL}$ YPD medium (10 $\mathrm{g} \mathrm{L}^{-1}$ yeast extract, $20 \mathrm{~g} \mathrm{~L}^{-1}$ peptone, and 20 $\mathrm{g} \mathrm{L}^{-1}$ glucose) at $30^{\circ} \mathrm{C}$ with $150 \mathrm{rpm}$ agitation for 48 hours, and then collected by centrifugation at $5,000 \times \mathrm{g}$ for 3 minutes at $25^{\circ} \mathrm{C}$, washed twice with distilled water, and then inoculated into $50 \mathrm{~mL}$ YPG medium $\left(10 \mathrm{~g} \mathrm{~L}^{-1}\right.$ yeast extract, $20 \mathrm{~g} \mathrm{~L}^{-1}$ peptone, $0.1 \mathrm{M}$ phosphate buffer adjusted to $\mathrm{pH} 6.0$,
$10 \mathrm{mM}$ disodium EDTA, and $10 \mathrm{~g} \mathrm{~L}^{-1}$ Synechococcus sp. strain PCC 7002 glycogen extract). Ethanol production was performed at $30^{\circ} \mathrm{C}$ and an agitation speed of $500 \mathrm{rpm}$ in 100-mL closed bottles equipped with a bubbling $\mathrm{CO}_{2}$ outlet and a stir bar under oxygen-limited conditions. Agitation speed was maintained with a magnetic stirrer (VARIOMAG Telesystem; Thermo Fisher Scientific, Waltham, Massachusetts, United States).

\section{Abbreviations}

3-PG: 3-phosphoglycerate; ADP: Adenosine diphosphate; AGPase: ADP-glucose pyrophosphorylase; HPLC: High liquid chromatography; OD: Optical density; SD: Standard deviations.

\section{Competing interests}

The authors declare that they have no competing interests.

\section{Authors' contributions}

SA designed the study and wrote the manuscript. AN performed the experiments and analyzed the data. SHH revised manuscript. $\mathrm{TH}$ designed the study and revised manuscript. JSC and AK coordinated the study. All authors read and approved the final manuscript.

\section{Acknowledgements}

The authors thank Dr Hiroshi Teramura and Dr Ancy Joseph for their valuable comments. This work was supported by the Core Research for Evolutional Science and Technology (CREST) of Promoting Globalization on Strategic Basic Research Programs of the Japan Science and Technology Agency. The study was also partially supported by a National Cheng Kung University project, as part of a second-phase 5-year 50 billion dollar grant from the Taiwanese government to JSC, and a Grant-in-Aid for Kurita Water and Environment Foundation to SA (Number 13A021).

\section{Author details}

${ }^{1}$ Department of Chemical Science and Engineering, Graduate School of Engineering, Kobe University, 1-1 Rokkodai, Nada, Kobe 657-8501, Japan. ${ }^{2}$ Core Research for Evolutional Science and Technology, Japan Science and Technology Agency, 3-5 Sanban, Chiyoda, Tokyo 102-0075, Japan. ${ }^{3}$ Organization of Advanced Science and Technology, Kobe University, 1-1 Rokkodai, Nada, Kobe 657-8501, Japan. ${ }^{4}$ Department of Chemical Engineering, National Cheng Kung University, No.1 University Road, Tainan 701, Taiwan. ${ }^{5}$ Research Center for Energy Technology and Strategy, National Cheng Kung University, No.1 University Road, Tainan 701, Taiwan. ${ }^{6}$ Center for Bioscience and Biotechnology, National Cheng Kung University, No.1 University Road, Tainan 701, Taiwan. ${ }^{7}$ Precursory Research for Embryonic Science and Technology (PRESTO), Japan Science and Technology Agency, 3-5 Sanban, Chiyoda, Tokyo 102-0075, Japan. ${ }^{8}$ Biomass Engineering Program, RIKEN, 1-7-22 Suehiro, Tsurumi, Yokohama 230-0045, Japan. 'Department of Food Bioscience and Technology, College of Life Sciences and Biotechnology, Korea University, Seoul 136-713, Republic of Korea.

Received: 21 October 2013 Accepted: 27 May 2014

Published: 11 June 2014

\section{References}

1. Ducat DC, Way JC, Silver PA: Engineering cyanobacteria to generate highvalue products. Trends Biotechnol 2011, 29:95-103.

2. Lopez PJ, Desclés J, Allen AE, Bowler C: Prospects in diatom research. Curr Opin Biotechnol 2005, 16:180-186.

3. Rosenberg JN, Oyler GA, Wilkinson L, Betenbaugh MJ: A green light for engineered algae: redirecting metabolism to fuel a biotechnology revolution. Curr Opin Biotechnol 2008, 19:430-436.

4. Melis A: Solar energy conversion efficiencies in photosynthesis: minimizing the chlorophyll antennae to maximize efficiency. Plant Sci 2009, 177:272-280

5. Aikawa $\mathrm{S}$, Joseph A, Yamada R, Izumi Y, Yamagishi T, Matsuda F, Kawai H, Chang JS, Hasunuma T, Kondo A: Direct conversion of Spirulina to ethanol without pretreatment or enzymatic hydrolysis processes. Energ Environ Sci 2013, 6:1844-1849. 
6. Choi SP, Nguyen MT, Sim SJ: Enzymatic pretreatment of Chlamydomonas reinhardtii biomass for ethanol production. Bioresour Technol 2010, 101:5330-5336.

7. Harun R, Jason WSY, Cherrington T, Danquah MK: Exploring alkaline pretreatment of microalgal biomass for bioethanol production. Appl Energy 2011, 88:3464-3467.

8. Ho SH, Li PJ, Liu CC, Chang JS: Bioprocess development on microalgaebased $\mathrm{CO}_{2}$ fixation and bioethanol production using Scenedesmus obliquus CNW-N. Bioresour Technol 2013, 145:142-149.

9. Miranda JR, Passarinho PC, Gouveia L: Pre-treatment optimization of Scenedesmus obliquus microalga for bioethanol production. Bioresour Technol 2012, 104:342-348.

10. Dismukes GC, Carrieri D, Bennette N, Ananyev GM, Posewitz MC: Aquatic phototrophs: efficient alternatives to land-based crops for biofuels. Curr Opin Biotechnol 2008, 19:235-240.

11. Stevens SE, Porter RD: Transformation in Agmenellum quadruplicatum. Proc Natl Acad Sci USA 1980, 77:6052-6056.

12. Bennette NB, Eng JF, Dismukes GC: An LC-MS-based chemical and analytical method for targeted metabolite quantification in the model cyanobacterium Synechococcus sp. PCC7002. Anal Chem 2011, 83:3808-3816.

13. Ludwig M, Bryant DA: Synechococcus sp. strain PCC7002 transcriptome: acclimation to temperature, salinity, oxidative stress, and mixotrophic growth conditions. Front Microbio/ 2012, 3:1-14.

14. McNeely K, Xu Y, Bennette N, Bryant DA, Dismukes GC: Redirecting reductant flux into hydrogen production via metabolic engineering of fermentative carbon metabolism in a cyanobacterium. Appl Environ Microbiol 2010, 76:5032-5038

15. Kumaraswamy GK, Guerra T, Qian X, Zhang S, Bryant DA, Dismukes GC Reprogramming the glycolytic pathway for increased hydrogen production in cyanobacteria: metabolic engineering of $\mathrm{NAD}^{+}$-dependent GAPDH. Energ Environ Sci 2013, 6:3722-3731.

16. Xu Y, Guerra LT, Li Z, Ludwig M, Dismukes GC, Bryant DA: Altered carbohydrate metabolism in glycogen synthase mutants of Synechococcus sp. strain PCC 7002: cell factories for soluble sugars. Metab Eng 2013, 16:56-67.

17. Guerra LT, Xu Y, Bennette N, McNeely K, Bryant DA, Dismukes GC: Natural osmolytes are much less effective substrates than glycogen for catabolic energy production in the marine cyanobacterium Synechococcus sp. strain PCC 7002. J Biotechnol 2013, 166:65-75.

18. Hasunuma T, Kikuyama F, Matsuda M, Aikawa S, Izumi Y, Kondo A: Dynamic metabolic profiling of cyanobacterial glycogen biosynthesis under conditions of nitrate depletion. J Exp Bot 2013, 64:2943-2954.

19. Aikawa S, Izumi Y, Matsuda F, Hasunuma T, Chang JS, Kondo A: Synergistic enhancement of glycogen production in Arthrospira platensis by optimization of light intensity and nitrate supply. Bioresour Technol 2012 108:211-215.

20. Aoyama K, Uemura I, Miyake J, Asada Y: Fermentative metabolism to produce hydrogen gas and organic compounds in a cyanobacterium Spirulina platensis. J Ferment Bioeng 1997, 83:17-20.

21. De Philippis R, Sili C, Vincenzini M: Glycogen and poly- $\beta$-hydroxybutyrate synthesis in Spirulina maxima. J Gen Microbiol 1992, 138:1623-1628.

22. Ernst A, Böger P: Glycogen accumulation and the induction of nitrogenase activity in the heterocyst-forming cyanobacterium Anabaena variabilis. J Gen Microbiol 1985, 131:3147-3153.

23. Lehmann M, Wöber $\mathrm{G}$ : Accumulation, mobilization and turn-over of glycogen in the blue-green bacterium Anacystis nidulans. Arch Microbiol 1976, 111:93-97.

24. Ho SH, Chen CY, Chang JS: Effect of light intensity and nitrogen starvation on $\mathrm{CO}_{2}$ fixation and lipid/carbohydrate production of an indigenous microalga Scenedesmus obliquus CNW-N. Bioresour Technol 2012, 113:244-252

25. Sakamoto T, Bryant DA: Synergistic effect of high-light and low temperature on cell growth of the $\Delta 12$ fatty acid desaturase mutant in Synechococcus sp. PCC7002. Photosynth Res 2002, 72:231-242.

26. Webber AN, Nie GY, Long SP: Acclimation of photosynthetic proteins to rising atmospheric $\mathrm{CO}_{2}$. Photosynth Res 1994, 39:413-425.

27. Gómez-Casati DF, Dortassa S, Aon MA, Iglesias AA: Ultrasensitive behavior in the synthesis of storage polysaccharides in cyanobacteria. Planta 2003, 216:969-975.

28. Boussiba S, Richmond AE: C-phycocyanin as a storage protein in the bluegreen alga Spirulina platensis. Arch Microbiol 1980, 125:143-147.
29. Klähn S, Stglich C, Hess WR, Hagemann M: Glucosylglycerate: a secondary compatible solute common to marine cyanobacteria from nitrogen-poor environments. Environ Microbiol 2010, 12:83-94

30. Friedman O, Dubinsky Z, Arad SM: Effect of light intensity on growth and polysaccharide production in red and blue-green rhodophyta unicells. Bioresour Technol 1991, 38:105-110.

31. Yao C, Ai J, Cao X, Xue S, Zhang W: Enhancing starch production of a marine green microalga Tetraselmis subcordiformis through nutrient limitation. Bioresour Technol 2012, 118:438-444.

32. Behrens PW, Bingham SE, Hoeksema SD, Cohoon DL, Cox JC: Studies on the incorporation of $\mathrm{CO}_{2}$ into starch by Chlorella vulgaris. $J$ Appl Phycol 1989, 1:123-130.

33. Morsy FM: Acetate versus sulphur deprivation role in creating anaerobiosis in light for hydrogen production by Chlamydomonas reinhardii and Spirulina platensis: two different organisms and two different mechanisms. Photochem Photobiol 2011, 87:137-142.

34. Serebryakova LT, Sheremetieva M, Tsygankov AA: Reversible hydrogenase activity of Gloeocapsa alpicola in continuous culture. FEMS Microbiol Lett 1998, 166:89-94.

35. Huesemann MH, Hausmann TS, Cater BM, Gerschler JJ, Benemann JR: Hydrogen generation through indirect biophotolysis in batch cultures of the nonheterocystous nitrogen-fixing cyanobacterium Plectonema boryanum. Appl Biochem Biotechnol 2010, 162:208-220.

36. Tandeau de Marsac N, Castets AM, Cohen-Bazire G: Wavelength modulation of phycoerythrin synthesis in Synechocystis sp. 6701. J Bacterio/ 1980 142:310-314.

37. Stevens SE, Pat Patterson CO, Myers J: The production of hydrogen peroxide by blue-green algae: a survey. J Phycol 1973, 9:427-430.

38. Flores E, Romero JM, Guerrero MG, Losada M: Regulatory interaction of photosynthetic nitrate utilization and carbon dioxide fixation in the cyanobacterium Anacystis nidulans. Biochim Biophys Acta 1983, 725:529-532

39. Deng $\mathrm{Y}, \mathrm{Ye} \mathrm{J}, \mathrm{Mi} \mathrm{H}$ : Effects of low $\mathrm{CO}_{2}$ on $\mathrm{NAD}(\mathrm{P}) \mathrm{H}$ dehydrogenase, a mediator of cyclic electron transport around photosystem I in the cyanobacterium Synechocystis PCC6803. Plant Cell Physiol 2003, 44:534-540.

40. Izumi Y, Aikawa S, Matsuda F, Hasunuma T, Kondo A: Aqueous size-exclusion chromatographic method for the quantification of cyanobacterial native glycogen. J Chromatogr B 2013, 930:90-97.

41. Association APH: Standard Methods for the Examination of Water and Wastewater. 17th edition. Edited by Clesceri LS, Greenberg AE, Trussell RR. Washington DC: American Public Health Association; 1989.

doi:10.1186/1754-6834-7-88

Cite this article as: Aikawa et al:: Glycogen production for biofuels by the euryhaline cyanobacteria Synechococcus sp. strain PCC 7002 from an oceanic environment. Biotechnology for Biofuels 2014 7:88

\section{Submit your next manuscript to BioMed Central and take full advantage of:}

- Convenient online submission

- Thorough peer review

- No space constraints or color figure charges

- Immediate publication on acceptance

- Inclusion in PubMed, CAS, Scopus and Google Scholar

- Research which is freely available for redistribution 